\title{
Correction to: Systematic Review and Meta-analysis of Short-versus Long-Acting Granulocyte Colony- Stimulating Factors for Reduction of Chemotherapy- Induced Febrile Neutropenia
}

\author{
Paul Cornes · Pere Gascon · Stephen Chan · Khalid Hameed • \\ Catherine R. Mitchell • Polly Field · Mark Latymer · Luiz H. Arantes Jr.
}

Published online: October 29, 2018

(C) The Author(s) 2018

Correction to: Adv Ther

https://doi.org/10.1007/s12325-018-0798-6

The article "Systematic Review and Meta-analysis of Short-versus Long-Acting Granulocyte Colony-Stimulating Factors for Reduction of Chemotherapy-Induced Febrile Neutropenia", written by Paul Cornes, Pere Gascon, Stephen Chan, Khalid Hameed, Catherine R. Mitchell, Polly Field, Mark Latymer, Luiz H. Arantes Jr was originally published electronically on the publisher's internet portal (currently SpringerLink) on October 8, 2018 without open access.

The copyright of the article changed to $\odot$ The Author(s) 2018 and the article is forthwith distributed under the terms of the Creative Commons Attribution-NonCommercial 4.0 International License (http://creativecommons.

The original article can be found online at https://doi. org/10.1007/s12325-018-0798-6.

P. Cornes $(\bowtie)$

Comparative Outcomes Group, 9 Royal Victoria

Park, Bristol BS10 6TD, UK

e-mail: paul.cornes@yahoo.co.uk

P. Gascon

Department of Hematology-Oncology, Hospital

Clínic, University of Barcelona, C/Casanova 143,

08036 Barcelona, Spain

S. Chan

Nottingham University Hospitals, Hucknall Road,

Nottingham NG5 1PB, UK org/licenses/by-nc/4.0/), which permits any non-commercial use, distribution, and reproduction in any medium, provided you give appropriate credit to the original author(s) and the source, provide a link to the Creative Commons license, and Indicate if changes were made.

The original article has been corrected.

Open Access. This article is distributed under the terms of the Creative Commons Attribution-NonCommercial 4.0 International License (http://creativecommons.org/licenses/ by-nc/4.0/), which permits any noncommercial use, distribution, and reproduction in any medium, provided you give appropriate credit to the original author(s) and the source, provide a link to the Creative Commons license, and indicate if changes were made.

\section{K. Hameed}

Sheffield University, Weston Park Hospital, Whitham Road, Sheffield S10 2SJ, UK

C. R. Mitchell · P. Field

PharmaGenesis Oxford Central, Chamberlain

House, 5 St Aldates Courtyard, Oxford OX1 1BN, UK

M. Latymer

Pfizer Ltd, Ramsgate Road, Sandwich CT13 9NJ, UK

L. H. Arantes Jr.

Pfizer Inc, 235 East 42nd Street, New York, NY 10017, USA 